\title{
Cuando Chaxiraxi se convirtió en Candelaria
}

\section{Sergio Baucells Mesa}

Dr. en Prehistoria, Antropología e Historia Antigua de la ULL http://doi.org/10.31939/bierehite/2019.04

Lo primero es agradecer al Museo de Historia y Antropología de Tenerife por contar con mi presencia. No sé si luego se van a arrepentir. En estos tiempos que corren, hablar de la Virgen de Candelaria y todo esto, a lo mejor puede generar conflictos ideológicos, para el que los tenga. A mí no me resulta ningún problema. ¿Por qué pasa esto?.

Hoy hablaremos de la Virgen de Candelaria en diferentes fases, presentando esta lectura que les quiero aportar, como un espacio de reflexión. Esa construcción histórica que la sociedad canaria ha asimilado sobre el papel que tiene la virgen en la incorporación del aborigen al mundo europeo, debería ser, cuanto menos, reflexionada y habría que tener en cuenta nuevas lecturas. Porque parece que la asimilación del aborigen, la pérdida total de su identidad, fue un proceso muy complejo. En esa aculturación del aborigen para asimilar la cultura europea, hay una primera semilla, según las lecturas tradicionales, que sirvió de relato en la percepción que se tiene sobre la incontestable incorporación del aborigen. Su conversión temprana al cristianismo sería pues una pieza fundamental en la construcción de la nueva sociedad canaria. 
Como soy fan del método Stanislavski, yo cuando me meto en charlas, estoy dos meses con una empatía brutal y me convertí estos días en Chaxiraxi. Mi mujer no se dio cuenta, pero yo estaba ahí y era Chaxiraxi; en otros momentos era Antón Guanche. Esa especie de esquizofrenia que tenemos los historiadores. Pues claro, me empecé a ver algunas cositas por ahí que no tenía muy controladas y me topé ayer mismo, con un documental del ayuntamiento de Candelaria, que está muy bien, sobre la ceremonia. Hoy vamos a hablar poquito sobre la ceremonia y el ritual de los aborígenes, no quiero animar ningún tipo de conflicto, porque todo es respetable. Yo me quedé con una frase con la que culmina Antonio, mi adorado y mi querido amigo, profesor Antonio Tejera, en la que él alude a un enunciado que es universal para todos los canarios, y es que "la virgen de Candelaria es una clave, un eje esencial en el proceso de cristianización de la isla de Tenerife", quédense con esa idea.

¿Quién nos ha transmitido esa idea? ¿La propia virgen con una función mágica religiosa? ¿Las lecturas de los aborígenes en ese conflicto que ellos tuvieron entre sí para poder cargar la virgen...? Bueno hay un mundo aquí. O toda una elaboradísima, complejísima, no voy a decir consensuada, estrategia misional, que acaba definiendo exactamente lo que se puede considerar como una pieza clave en esa cristianización. Yo no pretendo mostrar nuevos datos sino dimensionar el evento desde la óptica de los estudios de aculturación, partiendo de una serie de interrogantes para podernos entender; y voy a ser lo más sencillo posible.

El episodio del cual vamos a hablar aquí, es el del «encuentro», el del hallazgo, el de las visiones que tienen los aborígenes canarios, en este caso los guanches, de una talla gótica pequeñita del siglo XIV - XV. Ese hallazgo y las distintas lecturas que ellos mismos hicieron sobre esa imagen, nos van a dar las claves sobre una evolución ideológica muy compleja que acaba por convertirlos al cristianismo. 
Por lo tanto, en ese hallazgo hubo un evento aculturativo, ¿Por qué no? Claro que sí. Es un elemento que hay que tener en cuenta con su contexto ¿Cuándo ocurre? ¿Cuántas etapas tiene? Porque la imagen aparece en un clima absolutamente legendario y confuso y solo podemos rastrearla a partir de algunos datos, donde estuvo es lo importante; y donde acabó. Y entre ese donde estuvo y donde acabó, si hubo cambios en la percepción del indígena sobre esa imagen. Ya les adelanto que, efectivamente, claro que los hubo, pero hay que tratarlos desde este punto de vista, desde una concepción, digamos, aculturativa.

Hay que redimensionarlo desde el problema complejo que significa la aculturación. Esto de la aculturación, para poder hablar un lenguaje común, es un vocablo nuevo, un neologismo que apareció en los años 30 en la etnología norteamericana. Acuérdense de aquella visión maravillosa del encuentro entre los sioux, cheyenes o comanches y los americanos. Eso lo hemos visto todos en las películas. Aquellos antropólogos, yo los envidio tanto, se encontraron de frente con esas sociedades, digamos que con sus «objetos de estudio», cuyas poblaciones llevaban 300 años de contacto con los europeos. Por cierto, esa imagen que tenemos del indio americano a caballo -que da cuenta de la llamada horse culture entre las tribus nativas de las grandes llanuras-, saben ustedes que es una respuesta aculturativa, un elemento que introdujeron los españoles en su momento -parece que desde el segundo viaje de Colón-, y que fueron asumidos por los indios norteamericanos en el siglo $\mathrm{XVII}$.

En ese contexto, los antropólogos norteamericanos empiezan a cuestionarse cómo poder tratar ese problema tan complejo y tan humano, como es el contacto entre sociedades. Entonces acuñaron ese término de acculturation. Y claro, cuando yo me inicié en este mundo, hace más de 20 años, que el tiempo vuela, una de mis obsesiones era preguntarme enconadamente ¿Qué es aculturación? 
Porque la acepción que ellos habían planteado era excesivamente genérica, según la cual, la aculturación es «todo cambio cultural generado del contacto entre grupos de individuos que tienen diferentes culturas». Siendo así, casi todos los procesos humanos de cambio cultural son respuestas aculturativas, se dan en el contexto de contactos, pues nunca hemos estado aislados. A mí me gustaba profundizar un poquito más. Yo creo que ahora mismo vivimos en un mundo globalizado y todo es aculturación desde ese punto de vista genérico. Que yo lleve unas Nike o que cualquiera las lleve, aquí o en Singapur... todo eso es préstamo cultural, eso es difusión; difusión de elementos formales, que en realidad no están trastocando para nada otras formas culturales más complejas.

Por lo tanto, para mí, la «aculturación» que yo manejo es una expresión cultural, es decir, formas de representarse, de cambios estructurales profundos e importantes, porque si no son así, no interesan. Desde ese punto de vista es como nosotros lo vemos. Esos cambios culturales están condicionados por una estructura que llamamos proceso de interacción, en la cual se están dando relaciones complejas entre sociedades distintas. A mí me gusta llamarlas formas de interacción interétnicas.

Bien, tenemos un contexto perfectamente definido en Canarias en el caso que nos ocupa, que es el que llamamos «proceso de interacción», que es aquel que se manifiesta en la transformación progresiva, cualitativa e importante, que están sufriendo las sociedades aborígenes cuando entran en contacto con el resto de sociedades. Claro, si tenemos en cuenta la ponencia de nuestra compañera de antes, podríamos ubicarnos desde el principio de los romanos, un mundo en el que yo no me quiero meter, ni romanos, ni fenicios, porque hasta ahora no me he tropezado con un romano plenamente en Canarias, me he encontrado con ánforas, sí, pero estamos hablando de estructuras permanentes, que es lo que a mí me interesa. 
Decía, mi adorado Gordon Childe que "la historia se ocupa, no de los granos en el desierto, sino de las playas". Para mí, el verdadero proceso de interacción que va a condicionar la introducción de transformaciones en las sociedades aborígenes, es el que se inicia con esas expediciones en el siglo XIV, en los años 30-40, que sí que están perfectamente documentadas y donde además hay relatos del contacto con los aborígenes; hay muchísimas fuentes de este tipo de cuestiones. A partir de ahí empezamos a observar indicadores aculturativos, determinados cambios importantes, entre ellos, por ejemplo, la intromisión de nuevos elementos, como una talla gótica. Esto no culmina con la conquista, sino con ese dilatado proceso de colonización del siglo XVI, en el que hay que renegociar constantemente la ubicación de las sociedades aborígenes con lo que ha llegado de fuera, en ese trasplante institucional, político y económico que se llama mundo feudal tardío europeo.

Además, podemos periodizarlo. Dependiendo de las islas, podemos definir las etapas del proceso de interacción, que en mi opinión serían cuatro: contacto, preconquista, conquista y colonización. Las cronologías son diferentes según las islas, porque los factores históricos las condicionaron en función de la llegada de los de fuera, en momentos diferentes. Esto es muy interesante porque, mientras en Lanzarote, como bien sabemos, y en Fuerteventura, la conquista se inicia con los normandos en 1402, la conquista en Tenerife y Gran Canaria, en esos momentos, está en una fase de contactos esporádicos, muchas veces con esa gente de los señoríos que acuden, ya lo vamos a ir viendo, a Gran Canaria y a Tenerife a contactar con esa islas no insumisas como ellos hablan, a intercambiar productos $y$, bueno, a hacer otro tipo de cuestiones sobre las que ya hablaremos.

Bueno, en el caso de Tenerife, las etapas de contacto se pueden determinar más o menos. En 1336 conocemos algunas de las pri- 
meras expediciones documentadas, puede ser que haya algunas anteriores evidentemente. Pero a partir de 1364, con el acto del Bufadero del cual, si quieren, podemos hablar después, se va a dar una nueva relación, una relación más política que tiene que ver con la creación de estructuras permanentes en las islas: ya no voy, comercio en la playa y me voy, sino que voy, me quedo e intento renegociar contigo determinadas alianzas. Es la etapa de preconquista que veremos luego.

Estamos por lo tanto en Tenerife en los albores de la conquista, donde ya se produce otro tipo de relaciones. Lo importante de todo esto, es que estos contextos son distintos y van a condicionar claramente el proceso de asimilación de los aborígenes y, también, la lectura que nosotros podamos plantear sobre qué papel tuvo la Virgen de Candelaria en todo esto.

¿Cómo podemos estudiarlo? Me gusta reclamar la disciplina de la etnohistoria, porque es la reformulación del método etnohistórico el que nos permite plantearla precisamente como el conjunto de aquellos estudios ligados a los procesos de aculturación. En su momento yo la definí así: "la etnohistoria es el estudio de procesos de interacción que se establecen entre sociedades ágrafas y sociedades con escritura, que dan cuenta de aquéllas". Irma Mora me puede matar, que anda por ahí. Las sociedades canarias ¿Eran sociedades ágrafas? No, pero también es incontestable que el aporte de los textos que conocemos de ellos y, sobre todo, su grado de legibilidad, es ínfimo. No podemos manejar eso de la misma manera que una bula u otros textos que son perfectamente descifrables. Otra cosa interesante y no quiero meterme en conflictos, es que conocían un tipo de escritura, pero ¿quiénes la conocían? ¿todas las clases sociales aborígenes, guanches? Estoy seguro que no, solo algunos, digamos, las élites 
Y precisamente esa visión de los otros, los individuos que provienen de la sociedad que sí poseen una escritura para nosotros legible, sobre la sociedad que no la tiene supone la única documentación escrita -con lo relevante que esto para nosotros- sobre esas sociedades aborígenes. Esta información, sumada a la que nos proporciona la arqueología y la antropología, es la que comporta lo que llamamos fuentes etnohistóricas. En efecto, también contamos con una arqueología del contacto incipiente, que nos da algunos materiales, algunos registros de esos periodos y nos faltaría la otra pata de la etnohistoria, que es la antropología. Lo que pasa lamentablemente en Canarias, es que no contamos con «guanches vivos», por mucho que nos duela, porque si no, haríamos entrevistas orales, cuestionarios, investigaciones etnográficas con ellos, que si se pueden evaluar en otros mundos.

¿Qué hacemos con esta pata que cojea del guanche entrevistado? Pues lo podemos deducir a partir de nuestras crónicas, nuestras relaciones, nuestras visiones primarias sobre los aborígenes, la documentación eclesiástica, las bulas papales, las cartas concejiles, la documentación familiar, la documentación señorial, los protocolos notariales... En todo ese tipo de documentos, de los cuales afortunadamente sí tenemos bastantes en Tenerife, el guanche está absolutamente presente. Y lo está en todas las etapas del proceso de interacción. Lo está en la información que nos llega de las primeras exploraciones europeas y lo está plenamente en la realidad impositiva de la colonización del siglo XVI. Es más, después de informaciones que me llegan de los registros arqueológicos de Las Cañadas, seguimos encontrándonos al guanche hasta el siglo XVII, con lo cual imagínense ustedes, la complejidad con la que nos enfrentamos.

Bien, por lo tanto, con este maremágnum de documentación puedo plantear una forma de observarlos, la lente con la que vamos observarlos. Pero es fundamental tener claro cuáles son los fac- 
tores históricos y que condicionan ese proceso de interacción. En Canarias, hay que definir primero como son los sujetos, quienes se están enfrentando, en este caso, una sociedad aborigen en todas las islas, con otra sociedad que entra dentro del circuito tardomedieval. Hay que definir también las diferentes formas en las que se relacionaban, eso es interesante y lo voy a tener presente en toda la charla.

Hay diferentes formas de interacción, no es lo mismo el plano político, que el plano ideológico o que el plano económico, para sintetizarlo un poco en tres grandes pilares. Porque los agentes que ahí interactúan no son los mismos, ni el grado de imposición que se va utilizar, ni los objetivos que se persiguen. Luego insistiré un poquito en todo esto.

Y después, teniendo todos estos elementos, ya podemos empezar a observar y definir qué es lo que ha cambiado en una sociedad o en otra. Yo me centré en lo que cambió en la sociedad guanche, qué indicadores aculturativos tenemos o, también, permanencias culturales, que también puede ser, para luego determinar un tipo de resultado que, en el caso de los guanches, yo planteo que es un proceso de asimilación, porque no es lo mismo asimilación que integración.

Un tipo integrado es aquel que vive, por ejemplo, en el barrio chino de Barcelona. ¿Por qué? porque forma parte de nuestro sistema productivo, nuestras relaciones sociales de producción, trabaja como tal, es empresario o no, trabaja con este otro... sin embargo mantiene buena parte de todos aquellos elementos formales que lo definen como cultura. Sin embargo, un tipo asimilado, lo primero que hace es despojarse de la lengua, luego despojarse de los avatares que lo concilian como guanche en su momento. 
Nos enfrentamos por lo tanto a un modelo de formación social, incluso formación social desde el punto de vista clásico, que soy un trasnochado marxista, porque a mi me gusta definir las formaciones sociales desde elementos y categorías, que son perfectamente reconocibles por todos. Porque es que si no, cada uno define el sistema social como le da la gana. Pues no, a mí me gusta tener un método, soy un maniático en eso, un recetario, como decía mi amigo Felipe Bate.

¿Cómo definimos un sistema o formación social? Tendremos que ver su sistema productivo, tenemos que ver cuál es la posición de los individuos en las relaciones sociales de producción, es decir, el tipo de propiedad, cómo se retroalimenta ese sistema a partir de la ideología, supraestructura, etc. Claro, encontramos diferencias, en las que ahora me voy a meter.

Además, todo eso se particulariza en un «modo de vida» que, básicamente, en Tenerife, es el ganadero-recolector, por decirlo de alguna manera, con una pequeña producción de trabajos artesanales, para cubrir las necesidades domésticas. Frente a ella un modelo clasista, una sociedad clasista. También era clasista la guanche, pero un clasismo inicial, incipiente, donde la propiedad no está sobre la tierra, ni sobre los ganados, sino sobre la fuerza de trabajo. Bueno no voy a meterme en más. Frente a esta sociedad europea que determina otros tipos de forma de vida. Estos son los dos sistemas que se enfrentan, o que interactúan. Hay gente que usa la palabra interactuar desde un sentido «amable» para acentuar una cierta docilidad en la relación entre los que interactúan: como me decía un gran amigo, "parece que venían aquí y que estábamos esperándolos con el ukelele, -Hola amigo y tal...-". No hombre, quiero aclarar que para mí la palabra interactuar, lo único que dice es que hay una relación entre uno y otro, no les estoy diciendo si es de imposición, no imposición... 
Bien. Dicho todo esto, no sé si es demasiado para estas horas, pero a partir de aquí, una vez definidos los tipos sociales, podemos analizar esas diferentes formas en las que se relacionaron ¿Para qué? Para poder ubicar el evento de la aparición de la Virgen de Candelaria. No solo la aparición, sino toda su traducción por las lentes guanches.

Las primeras etapas, como bien les dije antes, eran las de Precontacto y Preconquista ¿Qué pasa en Tenerife en estos momentos? Digamos que hay una preeminencia del plan de interacción económico. La gente viene por aquí, mallorquines, portugueses, florentinos, genoveses, castellanos... esporádicamente, eventualmente, periódicamente... Muchos ya conocen hasta por donde tienen que llegar y se produce una forma de relación económica. Esa relación económica, como yo la defino, en muchos casos es de intercambios recíprocos y, en otros, ustedes lo saben perfectamente, con ese comercio de playa donde yo te espero, tu llegas, tú me das esos elementos que me interesan...; está muy condicionado, evidentemente, por los intereses mercantiles de esta sociedad europea ¿Qué es lo que vienen a buscar aquí? Bueno en las fases de mayor imposición, porque todo no es intercambio recíproco, sino que también hay cabalgadas de razias, interesan esclavos. Pero interesan también ganados, cebo, sangre de drago, orchilla, etc. ¿Y a nosotros? O, bueno, a nuestros..., el rollo de la identidad se me metió ¿no?, como les dije, el método Stanislavski, yo soy un guanche ya ¿A nosotros que nos interesaba? Evidentemente aquellos elementos que no encontrábamos en Canarias, los elementos de metal. Les voy a decir, hay una cosa que a veces perdemos de vista y es que estas sociedades conocían el metal perfectamente. Pero qué curioso tiene que ser, llegar nuevo a unas islas en las que un elemento, una herramienta que era cotidiana para ti, no existe ¡Ojo! ¡Qué putada! y ¡Perdón! Tengo que expresarlo y lo saben muy bien los que han trabajado la industria lítica, como hay mecanismos ahí que intentan simular el trabajo con el metal. Bueno, detrás de esto hay un mundo. 
Se han encontrado elementos, monedas, clavos... en contextos arqueológicos aborígenes, con lo cual nos están indicando esa fase de contacto. Esto con respecto a la preminencia del plano económico. En el plano político también hay una vocación de anexión y están ahí los sucesos de Diego García de Herrera y no me quiero extender mucho de verdad, porque si no podríamos estar horas... pero es tan apasionante todo esto que es que el acto del Bufadero lo que está señalando en 1464, es una relación que se intenta establecer desde el punto de vista político. Un señor, Diego de Herrera, que viene con el obispo, además viene a las islas, no solo a Tenerife sino a Gran Canaria, con el "Pacto de las Isletas" y hace un pacto, ahora que está tan de moda lo de los pactos y ahora que está tan de moda también las "performances" y las "fake news". Ese pacto no sirvió para nada o, por lo menos, para lo que Diego de Herrera creía que podía servir. Porque es una especie de ceremonia de enfeudación, algo muy medieval, en la cual parece que, según se recoge en el acta, que es lo que interesa, los nueve menceyes en los que estaba repartido el territorio en ese momento la isla, parece que hacen un acto de delegación, enfeudación a su supuesto señor. Por lo tanto, tenían que pagar tributos y todo ese tipo de cuestiones.

Documento que a Diego de Herrera le interesó presentar ya que también fue el titular de estas islas, lo cual nunca le sirvió para nada. Pudo servir para otras cosas que nos interesan más, que es, por ejemplo, la construcción de un eremitorio en Güímar o la construcción de la torre de Añazo en Santa Cruz, en varias fases, porque fue destruida...

Estamos en el plano que nos interesa, el plano ideológico. Nos enfrentamos en estas primeras etapas, a una dilatada fase de acción misional con un objetivo, que es el de convertir a esos gentiles que viven en otras islas, etc. Encontramos varios episodios y eventos, varias fases. Una primera fase es la que tiene que ver con la instalación de la diócesis de la Fortuna en Telde, en épocas muy 
tempranas, con una vida bastante corta.

Una segunda fase que tiene que ver con la instalación de la diócesis del Rubicón en Lanzarote y con la acción misional franciscana del convento de San Buenaventura en Fuerteventura que, por cierto, se cree que hay una conexión ahí y lo vamos a disfrutar. Son esos franciscanos asociados a fray Diego de Alcalá, en una fecha que va más o menos entre 1425 - 1450; y nos estamos acercando a la fase que nos interesa.

¿Estas fases condicionaron en algo a los guanches de Tenerife? No lo sabemos, pudiera ser. Es probable que la imagen de la Virgen de Candelaria fuera traída por los franciscanos de Fuerteventura. Hay quienes dicen que sí. Yo me inclino a pensar que, bueno, había una estructura aquí mucho más fiable que inaugura fray Alfonso de Bolaños en esa tercera fase que ya sí condiciona perfectamente a Tenerife y es la que tiene que ver con la instalación de una plaza permanente en Güímar, no sabemos exactamente bien, pero yo me inclino a pensar que es la zona de Achbinicó, en la propia cueva o por ahí, donde hay una presencia de franciscanos y, evidentemente, esta es la clave para entender la aparición de la Virgen. Con todo esto, no estoy diciendo nada nuevo.

Aunque hay lecturas que nos retrotraen a algo mucho más anterior. ¡Hombre! yo creo que, si tú quieres introducir una serie de cambios en la sociedad con la que tu estas contactando, es mejor que tu vayas por ahí y les vayas explicando lo que es esta escultura. 0 bueno, en todo caso, pusieron la imagen ahí, y a los pocos años ellos ya estaban allí. En fin, esto es algo de lo que podemos hablar.

Sabemos que entorno a 1458 está funcionando el eremitorio de Güímar, del cual tenemos pocas noticias. Por lo tanto, yo creo 
que esa fecha puede marcar su presencia ¿Por qué lo sabemos? Pues por la documentación que tiene que ver con la declaración al ministro general de la Orden de los minoritas que asume bajo su jurisdicción, bajo su tutela, esa misión. Porque es una misión, que es la de convertir a los Guanches de Tenerife. Bien, hasta ahí sabemos que hay una presencia de misioneros franciscanos en las costas de Güímar. Sabemos también que en el 62, muy poco después de que la misión de Canarias se convierta en una Vicaría autónoma, se le conceden mayores recursos bajo liderazgo de una figura fundamental que es Bolaños, que es, digamos, el que se va a presentar al papa como el gran misionero, no solo de Canarias, sino de la costa africana. De hecho, creemos que este elemento hace que los otros planos que hemos visto, el plano económico, los intercambios, e incluso el político, estén muy condicionados por la presencia de los franciscanos, aunque también condicionó su ruptura y que la presencia franciscana fuera absolutamente efímera.

Fíjense lo que declara en 1477 la pesquisa de Cabitos. Podemos aclarar que es esto de la pesquisa, esa orografía de la corrupción. La corrupción no es un problema contemporáneo, en esta época había mucha más corrupción que ahora. Al igual que cuando luego hablemos del franquismo y lo siento mucho, pero el franquismo era un sistema corrupto de arriba abajo. Pues el sistema de relaciones de la Corona, no solo la Corona, sino esos poderes que tenían atribuidos los señores feudales, eran absolutamente corruptos. Bueno hay una auditoría, por así decirlo, una investigación que atañe a Diego García de Herrera, en la cual la gente de Lanzarote está pidiendo pasar a la jurisdicción real, porque en la señorial les va fatal. Y, en lo que a nosotros nos interesa ahora, en esas declaraciones resulta que hay un testigo, carpintero para más señas, que habla simultáneamente de la presencia de los franciscanos y de la presencia de Diego de Herrera o de sus allegados en Tenerife, cuando declara: "que sabe e vido que nueve reyes canarios de Tenerife, obedesçieron e besaron la mano por señor al dicho Diego de Ferrera". Lo que les dije: el «besamanos», que es una ceremo- 
nia feudal de vasallaje, una performance para tratar de decirles, «señores, ustedes no lo saben, pero acaban de reconocer que esta isla es mía y ustedes mis vasallos». Vale hubo un acuerdo, no dice cuándo, aunque sabemos que fue en 1464, que estuvo presente el señor Diego López de Illescas, Obispo de Canaria, y otros frailes, y que los supuestos vasallos “estuvieron así pacíficos”. A partir de ese momento parece que hay unos tratados, pactos, alianzas de paz, de concertaciones, de negociaciones, tras las cuales seguramente, por qué no, está presente el tema de la Virgen, ya luego les comentaré. Pero «estuvieron pacíficos» durante unos seis años, poco más o menos, y después “se quebró esta paz", hasta el punto que por aquel 1477 "los cristianos les fasen guerra a la dicha isla de Tenerife".

Por lo tanto, si partimos de la fecha de 1464 y unos seis años más, estamos hablando del 70 como momento de la ruptura. Mi propuesta es que el eremitorio de Güímar no duró más de doce años, a lo mejor una década. La existencia de los franciscanos estuvo muy condicionada por las cabalgadas que provenían de los señoríos de Lanzarote y Fuerteventura, que fueron los que rompieron o quebraron esas paces de las que habla este vecino. Tanto el origen, que pudo permitir el inicio de esta misión de los franciscanos o la de la torre de Añazo, como la destrucción de ambos sitios o emplazamientos, estuvieron muy condicionados por esas relaciones interétnicas, nunca debemos olvidarlo.

Por lo tanto, a mí lo que se me plantea ya como reflexión, es ¿cuál fue la magnitud real de las conversiones que esos franciscanos hicieron sobre los aborígenes en una década? Una década que no tiene por qué ser de instalación permanente, sino que puede ser de idas y venidas de esos franciscanos ocupados en aprender el amazigh, para poder comunicarse con los aborígenes, tratar sus lenguas, aculturar a personalidades del mundo guanche para que ellos actúen también de intermediarios aculturativos, etc. ¿Cual 
fue su magnitud? Miren, esta es la bula Pastoris aeterni de Sixto IV que se emite en fechas muy cercanas (1472) cuando probablemente el eremitorio ya no existe, pero sí estaba muy cercano. Hay una información que fue dada directamente por el ermitaño Alfonso de Bolaños, recordemos, el franciscano que llevaba la misión de Canarias en Güímar, que él le plantea al papa. Una visión absolutamente espectacular de esas conversiones, porque lo que está pidiendo aquí, lo que se le concedía aquí, eran privilegios y la creación de la nunciatura de Guinea y más recursos para poder llevar a cabo esas misiones en Canarias y en el norte de África, en la costa de África. Y lo que llega a plantearle Bolaños es que, en Tenerife, había "miles de paganos naturales que han sido convertidos y adoctrinados". Esta simple mención ha servido para construir el relato sobre la aculturación temprana de los guanches sustentada en la evangelización, que ha manejado buena parte de la historiografía tradicional canaria y, como resultado, ofreciendo al resto de la sociedad canaria una lectura deformada del proceso de aculturación. En esencia, se plantea que ¡tres! misioneros franciscanos, que no eran más, Bolaños y dos más, convirtieron a miles de paganos, como los llaman aquí, en Tenerife.

Yo creo que aquí se está teniendo una visión eurocéntrica y muy complicada de mantener, pero que se ha mantenido a lo largo de nuestra historiografía. Es decir ¿El papel de esas conversiones fue tan duradero? Estamos hablando de un momento demasiado interesante para concebirlo como anecdótico: “iseñores, que tenemos documentos de 20 años antes de la conquista que hablan de miles de convertidos!". Prácticamente en Tenerife eran ya cristianos. Es la idea de la predestinación, además de estar predestinados a recibir el cristianismo de forma abierta, ha generado una especie de lectura mítica acerca del papel del cristianismo en la asimilación de los aborígenes. Es decir ¿Estos franciscanos tenían superpoderes? ¿O estamos hablando de un «optimismo histórico cristiano»? Aquí debería poner optimismo historiográfico cristiano ¿A qué me refiero? A que en buena parte de nuestros historiadores, a los 
cuales yo respeto muchísimo, no solo del siglo XX, sino desde los cronistas históricos, ha preponderado este tipo de lecturas, una postura absolutamente eurocéntrica sobre el papel que tuvieron estas conversiones sobre los aborígenes.

A los aborígenes se les trata, en algunos casos, como buenos salvajes que están predispuestos de forma pacífica a adoptar el cristianismo, simplemente, ya lo veremos luego, con la presencia de una imagen mágica. Pero es que se dice así desde los propios historiadores del siglo XX. Antonio Rumeu por ejemplo, quien se merece todo el respeto posible porque gracias a él, podemos manejar un impresionante volumen de datos empíricos, fue un gran documentalista, que además sabía lo que es la crítica histórica de los textos, pero que aplica cuando le interesa y cuando no, no. En la interpretación que él hace de la bula del 72, dice que el plato fuerte de la misión era Tenerife donde la conversión de indígenas había dado resultados espectaculares ¡Claro! Ni si quiera él se plantea dudar de esa frase sobre los miles de paganos convertidos. Yo sí, a mi sí me gusta dudar. Además, en toda esta lectura tradicional tenemos, desde ese eurocentrismo de las propias primeras fuentes históricas que, evidentemente, están vinculadas a la visión del europeo que viene a cristianizar a esos gentiles, a una epistemología basada en la providencia, es decir, que las cosas suceden por seres supremos divinos que nos guían. Rumeu de Armas en más de una ocasión, habla de Alonso Fernández de Lugo recogiendo literalmente las cosas de Espinosa como, por ejemplo, que Alonso de Lugo sobrevive a la batalla de la Matanza, por una cuestión providencial y él no lo desestima por ninguna parte.

Bueno, como digo, una epistemología fundada en la providencia. Se asume también, toda esa teatralización del barroco, el dramatismo, los mártires franciscanos que fueron aniquilados y tal, pero que, así y todo, ellos lograron incubar el cristianismo, la luz, en esas sociedades salvajes. Eso está todo presente en esta lectura e, 
incluso, hasta este historicismo más reciente, donde yo ya incluyo la figura de buena parte de nuestros historiadores tradicionales. Es ese historicismo basado en los grandes personajes, en el que el motor de la historia son las grandes personalidades, en este caso, tres franciscanos que por sí solos, son capaces de crear transformaciones sociales tan importantes, como la asunción de toda una cosmogonía que es ajena a los aborígenes, en muy poco espacio de tiempo. Estamos hablando de un momento que en Tenerife como mínimo, podrían haber 15.000 habitantes. Creo que este tipo de reflexiones habría que tenerlas en cuenta. Sea por la asunción de una epistemología basada en la providencia o fuera porque, desde la sublimación de la idea de progreso, la civilización cristiana es retratada como superior, el impacto de los misioneros nunca se estima en términos cuantitativos sino cualitativos - «eran pocos pero laboriosos en su tarea», parecen afirmar -, y eso, a la hora de establecer un análisis crítico fiable resulta siempre peligroso.

Dicho todo esto, el programa de conversiones debió ser un fracaso, evidentemente $y$, además, era muy complicado en estas etapas, antes de la conquista y lo fue después. A mí me enseñó un profesor de la Universidad de La Laguna, que las cosas que cambian más lentas son las que están en la cabeza. Cuando tu mundo real, material, de subsistencia, que reproduce la sociedad de verdad, no se ha modificado, es difícil que la ideología que está sustentando ese mundo se modifique porque sí. Bueno si quieren luego seguimos con este tema de elucubraciones.

Pero respecto a esto, creo que este episodio de la aparición de la Virgen sí está ligado a la presencia de los franciscanos, por lo tanto, hay una tutela franciscana incuestionable en la introducción de la imagen, sea por los franciscanos de Betancuria o sea, yo creo, por los que están instalados en el eremitorio de Güímar. 
Una primera clave para entender lo complejo que fue la asunción del «acontecimiento mariano» por los guanches y por la propia sociedad canaria, es la leyenda de la aparición de la Virgen, hecho fundamental para la construcción de una sociedad y todo este tipo de cosas. Y es que hay una gran proximidad entre la probable introducción de la imagen y la clausura del eremitorio. Todo esto ayudó a un clima confuso y legendario. No encontramos noticias sobre ese episodio tan ancestral y supuesto mito fundacional del cristianismo en Canarias. No encontramos más relatos hasta ciento veinte y pico años más tarde ¿Qué raro no? Es muy raro ¿Cuáles son esos relatos? Son los que nos aportan los primeros historiadores. Hay dos versiones sobre la aparición de la Virgen. La más conocida es la del dominico fray Alonso de Espinosa, que ustedes conocerán seguramente. Pero hay una anterior, la de un franciscano, curioso también, aunque no voy a entrar en ello porque el conflicto entre las órdenes religiosas me queda muy lejos, pero franciscanos y dominicos, todos sabemos que era una especie de Madrid-Barça de la época.

Está la versión de Fray Martín Ignacio, muy poco conocida, que difunde González de Mendoza en su relato de viajes y, que curioso, tiene ciertas diferencias con la de Espinosa. Martín Ignacio plantea que la Virgen aparece sobre una piedra y, probablemente en una cueva, mientras que Espinosa defiende que aparece en las costas de Chimisay. Luego también hay diferencias como que solo hay un pastor guanche que la ve mientras que todos conocemos la versión de Espinosa, con esa recreación con "dos naturales" y dos milagros, el tema de la piedra y todos estos datos que resultan riquísimos en términos tradicionales antropológicos y que tenemos totalmente asumidos los canarios como una lectura real y muy respetable.

Pero fíjense como la versión que parece que tuvo más solución de continuidad fue la de Espinosa, que es la que todos reproducimos, porque hay muchísimos autores -muchos de ellos absolutamente 
consagrados y sobre leídos en Canarias como Viana, Núñez de la Peña, Pedro del Castillo, etc.- que utilizaron la versión de Espinosa, mientras que la de Martin Ignacio se quedó en el olvido. Bueno esto es a título anecdotario porque, realmente, a mi lo que me interesa plantear es que, quizás, estas descripciones tardías sobre la aparición de la Virgen, lo que nos indica es que el relato sobre la propia aparición se fue elaborando muy posteriormente a la conquista y no es un mito que se recreara en tiempo de los guanches ¿Por qué? Porque cuando aparece la imagen -lo vamos a ver ahora- hay diferentes fases sobre la traducción que los guanches hacen sobre la imagen y su primera traducción realmente no fue religiosa, de eso estoy completamente seguro; no fue una traducción religiosa, no podía ser una traducción inmediata de contenido religioso. En una cultura que, primero, no entendía la complejidad del monoteísmo cristiano, sus axiomas, conceptos básicos, etc, etc. Hubo que mediar ahí una estrategia de sincretización que fue el primer elemento, el primer puente que se hubo de trazar para poder llegar a la asunción de la Virgen como una divinidad y, perdónenme por favor los cristianos en ese sentido: ¿La Virgen es una divinidad o no es una divinidad?, yo no entiendo cómo concibe realmente esta cuestión el monoteísmo cristiano, pero bueno... a ver si me entienden.

Bien, antes de adentrarnos a reflexionar sobre qué cambios ideológicos pudo conllevar la presencia de esa talla entre los aborígenes, vamos a detenernos en el contexto espacial. ¿Dónde fue ubicada esa imagen? Porque en ese traspaso de un lado a otro, también subyacen las propias lecturas que están haciendo los aborígenes sobre esa imagen. Esto es lo que yo llamo "los cambios materiales en las expresiones de sociabilidad". Cuando estudiamos procesos de aculturación, tenemos que detenernos también en aquellas expresiones que tienen que ver con la vida comunitaria de la colectividad y cómo pueden irse transformando, dado que son indicadores aculturativos. Cuando incorporas un nuevo elemento, como el convento en Betancuria o cuando transformas una antigua 
vivienda aborigen y la empiezas a tratar desde el punto de vista de los complementos del mundo medieval etc, etc., estamos hablando de transformaciones relativamente importantes. Por ejemplo, esto, por cierto, son los restos de un antiguo ingenio azucarero en la Gomera.

Los cambios culturales suelen darse bien por sustitución o por innovación, porque incorporas algo novedoso a esa sociedad. Por sustitución, que es algo muy interesante, sustituyes formalmente determinados elementos, que van a cumplir con las mismas funciones prexistentes de las anteriores. Yo creo que esto es lo que pasó. Después de un periodo relativo, es lo que va a pasar con la imagen de la Virgen hasta que pudo representar una transformación completa. Cuando aparece la imagen, según el relato de Espinosa, en este caso vamos a darlo por verídico, probablemente se traslada la imagen a lo que se llamaba las "moradas del Rey de Güímar". Estos que ven son los restos de la antigua ermita, la ermita moderna. En el 2006 se intervino en ella y, de repente, llegamos un día y la pala mecánica se la había levantado..., dicen que había sido un accidente. En fin, cosas que pasan.

Bien, se ve un poco mal, pero les voy a leer como es el relato de la primera ubicación que tuvo esa figura antropomorfa que entre los aborígenes tuvo que, no sé, sugerirles algo: "Con todo aquesto lse encuentran a la Virgen, sea en la cueva o en las costas de Chimisay, me da exactamente iguall propusieron de llevarla a la casa del Rey, para tenerla allí consigo; [...] tomaron a proseguir su camino, hasta llegar a las moradas del rey de Güímar, [...] y en el lugar de su habitación que llamaban Chinguaro. Donde, en un canto de la morada, sobre unas pieles de cabras y ovejas lque otras alfombras ni doseles no tenían), la pusieron con la decencia que sabían y podían hombres que no estaban acostumbrados a reverenciar ni a adorar dioses ni estatuas, ni tratar cosas divinas." Bueno, si que estaban acostumbrados, tenían sus propios seres supremos, incluso ídolos seguramente también. En Tenerife es difícil de constatarlo porque no tenemos esas ma- 
terialidades, pero evidentemente el concepto está, les aseguro que no eran ateos.

Les voy a contar una anécdota, cuando estuvimos excavando en Chinguaro... ¿ese emplazamiento era la cueva del rey? No lo sé, siempre estamos con estos debates improductivos. Por las mañanas se nos presentaba un personaje con unos papeles que nos decía: - “que esa no es la cueva del rey, que esa no es la cueva del rey!"; y nosotros: - "no estamos buscando ningún rey señor"-. Estábamos buscando, fíjense, algo tan raro como sedimentos arqueológicos. Él no podía entender que pudieras excavar simplemente una cueva -anónima- y su entorno, cuando precisamente son esos contextos los que más datos dan. Fue precisamente un poco como lo que pasó en Bencomo: - “Ay! es que no hay pruebas"; ¿Y qué quieres que te encuentres allí? ¿el Banot? No sé.

Bueno, la gente no entiende que en un registro arqueológico, lo más importante son las magnitudes de los materiales, de determinados materiales, como la cerámica, que representa magnitud y no anécdota. Fuera lo que fuera, ese entorno que, probablemente no era donde vivía el mencey, sí que pudo pertenecer a las moradas del rey. El mencey tendría diferentes espacios en el entorno donde él tener sus ganados, sus sirvientes, etc., etc., en ese espacio que hoy reconocemos como Chinguaro ¿Ustedes saben cuándo se levanta la ermita? La primigenia ermita de Chinguaro ¿Alguien lo sabe? Es complicado porque no hay muchos datos. Entre finales del siglo XVIII, creo recordar, y principios del siglo XIX. La aparición de la Virgen es de principios del siglo XV. Han pasado tres siglos ¿No les llama la atención que aquel lugar donde por primera vez estuvo ubicada, ese eje de la cristianización en Canarias, no hubiera tenido un reconocimiento anterior? Es complicado el tema de la implantación de ese mito de la recreación. Yo planteo que es muy posterior, precisamente en el siglo XVII cuando se da a pie a recrear ese mito de la aparición de la Virgen. 
En cuanto a las fechas de la ubicación en Chinguaro, yo creo que probablemente tenga que ver con las negociaciones del Bufadero. Es probable que en el 64. Piensen que Diego de Herrera probablemente venga con López de Illesca, que es el obispo de la diócesis del Rubicón, o con alguien allegado a él que también pudo concertar con ellos y decirles - "oye señores esa imagen que ustedes tienen ahí que lo sabemos por los franciscanos, envíenla inmediatamente a Chinguaro". Después la mandarán a Achbinicó, pero a eso voy un poquito más tarde.

Entonces el problema es que, desde nuestro punto de vista, todo parece indicar que el sentido original que los guanches debieron darle a la imagen, no fue en sentido religioso, sino de mera ostentación del prestigio, ese elemento tan conocido de las situaciones de contacto, en el cual un elemento exótico es incorporado y asumido por una sociedad que nunca ha visto ese elemento y que sirve para reforzar el prestigio de quien lo posee. Y ¿quién poseía esa imagen? Nada menos que el mencey de Güímar. Evidentemente sirvió para potenciar su prestigio, no solo frente a los de su bando sino, como dice en el texto, ante el resto: se dedicó a difundirlo por toda la isla: - "señores que yo tengo, no sé cómo la llamaría, una imagen absolutamente exótica que nadie tiene". Permítanme por favor, no se me coja al pie de la letra lo que voy a decir, pero puede ser asimilable a lo que sería un huevo de avestruz en ciertas sociedades que no lo conocían, un elemento absolutamente de prestigio, o una moneda.

Pero imagínense lo que sería una talla pintada en una sociedad donde ese tipo de iconografía no existía. Por lo tanto, lo que yo planteo es que hay una primera lectura de la imagen como un bien de prestigio, donde no intervienen para nada los elementos de culto, ni siquiera sincrético, sino que es un elemento ex novo para la sociedad que lo acoge; para, posteriormente y, probablemente coincidiendo con su bajada a la cueva de Achbinicó, eso sí, ahora ya 
intermediado probablemente por el acto del Bufadero del 64, sea ahí cuando probablemente empiecen a incorporarse elementos de simbiosis sincrética, de la síntesis entre las dos cosmovisiones.

Yo creo que esa consideración de bien de prestigio explica un poco la construcción tardía de la ermita, porque no se da hasta mucho después, cuando se reelabora esa tradición sobre el valor, digamos, plenamente cristiano de la imagen, cuando se considera que, efectivamente, aquel lugar donde estuvo hay que sacralizarlo de alguna manera.

Recapitulemos entonces. Tenemos una figura antropomorfa encontrada entre una sociedad guanche, más bien en lo que sería el bando de Güímar que se lleva a Chinguaro. Lo que planteamos es que esto es un bien de prestigio, un elemento de ostentación. A partir de un momento dado, es probable que coincidiendo con las negociaciones en Bufadero, se decide trasladar la imagen a la cueva de Achbinicó. Saben que este conjunto fue trabajado en su momento. Aunque ya Diego Cuscoy recogió algunos materiales en 1955 que se referencian en un pequeño inventario como monedas y medallas, fue con las labores de restauración de la ermita de San Blas cuando se llevó a cabo una excavación sistemática. Yo creo que fue la primera investigación en Canarias que se puede considerar de «arqueología de contacto», llevada a cabo por Cristo Hernández y Verónica Alberto, en los años 90 . Ellos consideran todo el emplazamiento un «conjunto arqueológico» que está definido por varios enclaves naturales: la cueva de Los Camellos, la cueva de San Blas, antigua cueva de Achbinicó, donde está hoy la ermita y también otras cavidades, como la cueva de los Condes, etc.

Luego hablaremos un poquito más de esa intervención, porque los resultados son muy interesantes para lo que vinimos a hablar aquí. Este fue el segundo emplazamiento seleccionado para ubicar la 
imagen, nosotros creemos que fue seleccionado por alguna razón evidentemente, porque este sitio quizás ya tenía un contenido cultual, ya era un espacio sacralizado por los propios guanches. Y todo parece indicar que así era. Pero fíjense que, en esa intermediación de llevar la Virgen a la cueva, aparece la figura de Antón Guanche, también una recreación mítica-legendaria; cuya existencia es algo complicada, pero probablemente, alguien o algo similar debió existir y no resulta nada infrecuente en los procesos de contacto. Son los famosos «lenguas» que servían de algo más que de intérpretes y funcionaban como agentes claves en la interacción interétnica. Parece que en este caso, Antón había sido llevado a Lanzarote o Fuerteventura donde es adoctrinado y luego regresa a Tenerife. Y parece que es a partir de la intermediación de Antón con sus coterráneos cuando se decide el nuevo traslado de la imagen de la Virgen. Antón les dice, fíjense, que "la lleven a una cueva que está junto a donde solían ordeñar sus ganados, y la llamaban Achbinico, que los cristianos llamarán después la cueva de San Blas. En ésta la pusieron, con la decencia que supieron y alcanzaron" porque, precisamente Antón, les había dicho que no era "decente cosa que la santa imagen este donde haya trato y tráfago de gente, porque no se le pierda el respeto".

Es decir, el traslado que hay de un sitio a otro, probablemente viene determinado porque la consideración que se tiene sobre la imagen ha cambiado o se pretende que cambie. No puede ser un elemento no sacralizado, un elemento exótico, que es como si yo le doy estas gafas a este tipo de sociedades que nunca han visto el plástico. Pues este caso sería algo parecido. El bien de prestigio se convierte ahora o se pretende convertir en un bien de culto ¿Pero qué culto? Sincrético, todavía sincrético. El sincretismo es una fase no culminada del cristianismo, donde van a confluir, de forma interesada, diferentes elementos de simbiosis entre ambas cosmogonías. ¿Complicado no? y ¿Cómo se plantea esa redefinición sincrética? Bueno, es el propio Antón Guanche quien, en su lengua, les plantea y les dice que esta mujer que ustedes ven es, diciendo en su pro- 
pia lengua; "Achmayex, guayaxerax, achoron, achaman la madre del sustentador del cielo y tierra", "para que por medio de su intersección vengáis al verdadero conocimiento de Dios que es el Guayaxerax que confesáis.

Aquí hay muchas cosas. En un comentario de texto con los alumnos, estaríamos un par de horas hablando de cosas. Vamos a no liarnos y, además, está Antonio Tejera aquí, que conoce perfectamente y ha estudiado en profundidad todos estos textos. El concepto de "madre del sustentador de cielo y tierra" sería el concepto digamos indígena -aborigen-, pero la incorporación nueva es la madre, una madre que sustenta al que «ustedes veneráis». Con lo cual, en verdad, lo que les está diciendo, es: "no tengan cuidado, si en verdad ustedes ya sois cristianos, aunque no lo sepan; porque ustedes ya están adorando a Guayaxerax que, en realidad, es el padre de esta señora." Bueno, perdón, es el padre y el hijo a la vez, en esa confusión yo no quiero entrar, porque yo no la entiendo, nunca lo he entendido y creo que nadie lo entiende.

Bien, una anécdota e, Irma, tu estas aquí, creo que la primera vez que aparece Chaxiraxi como voz, es en Abreu Galindo. Es curioso, no lo dice Espinosa sino Abreu. Todos sabemos que los dos manejaron alguna fuente común. Esa gente, con el italiano Leonardo Torriani, estaban ahí, visitaban los mismos bares o algo, porque las fuentes son las mismas, están usando los mismos datos y ellos en su recreación utilizan lo que quieran o no quieran. Entonces es curioso cómo Abreu es el que habla de Chaxiraxi y dice; "quiere decir la que carga el que tiene el mundo". Es un concepto que es muy bonito y a la vez profundo: la imagen de «la que carga al que carga al mundo». Por tanto hay un interés por profundizar en principios cosmogónicos que a los aborígenes les va a sonar pero que son relativamente diferentes, esto es el sincretismo. 
El sincretismo es un indicador aculturativo que funciona de manera universal, está presente en todos estos procesos tan complicados de aculturación, de cambios en las sociedades que están en contacto y que, además, desde el punto de vista religioso, tiene unos efectos, ahora sí, espectaculares, porque son muy llamativos. México es el paraíso del sincretismo, pero ahora mismo, hoy en el siglo XXI; lo es la Virgen de Guadalupe y no digamos otras concepciones en Chiapas, donde tuve la oportunidad de ver como allí hay rituales que combinan bebidas de refrescos con aspectos indígenas, pues porque eso les ayuda. Son incorporaciones de elementos que no trastocan tampoco lo de ellos, sino, simplemente, cumplen funciones que antes cumplían otro tipo de cosas como unas plantas aromáticas y ahora resulta que la Coca Cola les hace el mismo efecto, por lo que ellos lo utilizan sin ningún problema.

¿Quiénes eran unos maestros en todo esto? Los romanos. Los romanos eran la hostia, eran unos maestros en todo, fueron capaces de absorber, sin problemas, cualquier tipo de elemento exótico. Los incorporaban a su propia religión porque sabían que eso los hacía más fuerte. De hecho, absorbieron el cristianismo de la manera en lo que lo hicieron. Pero no me quiero detener ¿Qué es el sincretismo? Es una síntesis o fusión de elementos de distintas sociedades en contacto. Hay gente que dice que sincrético puede ser cualquier cosa, que no tiene porque ser religioso. Bueno, lo cierto es que en su dimensión historiográfica solemos asociarlo principalmente a elementos religiosos, cosmogónicos, cultuales, etc.

Estas son cosas que aparecen en Tenerife y que están en esta onda. Esta cruz que está en medio de unas cazoletas en San Miguel de Abona, ¿te acuerdas David? Esto es en Buenavista, una cueva de enterramiento aborigen y fíjense en lo que hay en esta loza. Claro hay que determinar de cuándo es esa cruz, pero tiene una forma bastante antigua. Bueno, en fin, lo que a mí me interesa como historiador, es que la combinación de elementos formales no siem- 
pre tiene por qué trastocar de una manera absoluta a la sociedad aborigen, sino, simplemente, incorporar una serie de elementos. Vamos a profundizar en las bases de ese culto sincrético con respecto a la Virgen de Candelaria en este momento.

Ya hablamos de la virgen de Candelaria que todavía para los aborígenes no lo es, es Chaxiraxi. Sin embargo, la selección de la advocación de Candelaria, no es una cosa hecha al azar, sino que hay diferentes elementos ahí que les ayudaban como estrategia misional a forzarla en su asociación con principios aborígenes. Estamos hablando del principio de fecundidad, representado iconográficamente en la figura de la madre que porta al niño y que se puede asimilar perfectamente a la idea de luz, principio supremo aborigen como todos sabemos. El fuego, que es una expresión ritual de esa luz para los aborígenes, está perfectamente representado en la idea de una candela encendida perpetuamente.

Bien, en las excavaciones que se hicieron en la cueva de Achbinicó, se encontraron niveles de fosas de enterramientos antiguos, algo común en las iglesias históricas. Creo que van desde el siglo XV hasta el XIX. En Canarias empiezan a enterrar fuera de las iglesias a principio del XIX. Pero también apareció un nivel aborigen anterior perfectamente reconocible, en el que, por lo menos sus investigadores lo plantean, hay una gran área de combustión, es decir, donde hubo fuego permanente durante muchos periodos de tiempo. Esta permanencia de fuego, fue lo que a ellos les convenció para afirmar que aquella cueva no era solo un lugar de esquilmo, que podía serlo, sino que tuvo consideración de espacio cultual para los guanches. Lo cual no ha de extrañarnos pues la práctica ganadera en este tipo de sociedades está muy vinculada a la propia expresión religiosa. Luego, tenemos la imagen de una Virgen «morenita» ¿Cuánto tiempo estuvo, esa talla gótica pequeñita recibiendo esas cenizas? Evidentemente todos sabemos que ese cutis moreno no venía sino de ese tipo de cuestiones. 
Por lo tanto, hay una posibilidad de asociar diferentes principios $y$, lo que yo vengo a plantear es que, en este mismo momento es cuando probablemente los aborígenes están asumiendo que esa imagen puede tener una consideración cultual, que ya la tienen en un espacio sagrado que es Achbinicó. Pero también había que pensar una cosa ¿Por qué la novedad no puede ser que lo que realmente se incorporó fue una nueva forma de ver, más que una forma de creer? Es decir, la presencia de la imagen, lo que pudo dar a los aborígenes, es que hay una nueva forma de comunicar su propio sistema religioso a través de una representación iconográfica, porque ellos desconocían esa forma de representar a una divinidad en un rol femenino. Es decir, el carácter icónico es importante y pudo ser esa gran novedad, más que esos principios de cambios ideológicos. Aquí el culto cristiano no está presente todavía, yo creo que tuvo que mediar una labor posterior de recreación de todo esto y convertirlo en el culto cristiano.

Efectivamente, cuando luego se rememora este episodio, que fue un culto sincrético, lo que se hace es sacralizar ese espacio inmediatamente después de la conquista. Es la primera sacralización de Alonso de Lugo en 1497 con una iglesia. Bien y vamos a ir mas rapidito. La figura de la Virgen de Candelaria, la hemos visto pasar desde un bien de prestigio en la casa del Mencey de Güímar, a un bien de culto sincrético. Pero ¿Qué ocurre a partir de la conquista? Es cuando encontramos un camino mucho más directo hacia la civilización, junto a un plano económico mucho más determinante en el futuro de la sociedad aborigen, con una conquista por medio, con imposición, relaciones más complejas, etc. No me voy a alargar. Y desde el punto de vista del plano de interacción ideológica, que es lo que nos concierne, evidentemente hay un proyecto de conversión religiosa muy complicado de realizar de buenas a primeras. Lo que vamos a tener y creo que tuvo mucho más efecto fue, no tanto la transmisión del principio ideológico, todos sabemos lo complicado que es una catequesis en las sociedades que no conocen estos principios, sino un modelo de trasplante de culto 
y de mimetismo. La gestualidad de los ritos, las procesiones, las rogativas, la erección de ermitas, etc. Los primeros aborígenes lo verían como una cosa absolutamente novedosa. Los descendientes de ellos ya empezarían a verlo como algo más común. Y los bisnietos como algo de su propia tradición.

Esto es lo que realmente determina la asunción de la Virgen de Candelaria como un hecho totalmente religioso, porque, además, ella tiene un papel fundamental, ahora sí, en ese trasplante de modelo castellano de organización del culto. Es muy común esto de particularizar el culto en algún lugar. Está la Virgen de la Peña, la Virgen de «no sé qué», el Santo de «no sé cuánto» y lo hacen tradición, lo convierten en un culto que integra a toda esa comunidad.

Bien ¿Cómo se plantea ese trasplante? Como digo, con la elección de muchas advocaciones, ermitas e iglesias que, indirecta o directamente, tienen que ver con la advocación de la Candelaria. Está el ejemplo de la ermita del Socorro. Hay una cosa curiosa, Espinosa en 1590 plantea que hay muy poca devoción en la ermita del Socorro y que no está reparada. Esto llama la atención. Lo que planteo es que es en estos momentos cuando se está impulsando la recreación del mito sobre la aparición de la Virgen de Candelaria. Creo que hay que poner en tela de juicio la devoción popular que tiene la Virgen de Candelaria en estos momentos. Hay otros datos sí, hay algunas procesiones de la Virgen de Candelaria, pero son perfectamente impulsadas por el Concejo de la Isla, porque ellos plantean que hay que potenciar el culto católico singular en Tenerife, como lo fue en Gran Canaria con la Virgen del Pino que, por cierto, no tiene nada de sincrético, pero hay un impulso por crear, porque además se rememore que sí fue sincrético, no sé si me explico.

Es en este momento, cuando se escribe la historia de Alonso de 
Espinosa, cuando se consolida como motor esencial que la Virgen es la conquistadora espiritual de los aborígenes. Otro elemento es que los guanches están predestinados al cristianismo y, un tercer elemento, es que el vehículo fundamental para esa conversión fue la Virgen de Candelaria. Pero todo este relato se elabora 120 años después de que ocurrieran esos hechos, o 130, o 150 años después. Es decir, hay una intención aquí por configurar, efectivamente, la recepción de la imagen como el elemento fundamental de la isla de Tenerife dentro de la vida pública, donde no están separados los planos religiosos de los políticos que todos sabemos. La Virgen supondría así la piedra fundacional de la asimilación guanche.

En este momento también, bueno, hay elementos más terrenales, como es el conflicto por hacerse con la administración de ese culto. Dominicos y franciscanos compiten entre ellos porque empieza a ser un elemento muy apetecible. En la medida que el Concejo va a potenciar el culto a la Candelaria, será muy apetecible la administración de todas esas ofrendas. Y después hay modelos que se repiten en Tenerife que tienen que ver tanto con la aparición de procesiones como con sus milagros. Por cierto, el libro de Espinosa no es un libro de Historia o el no quiso que lo fuera. Lo maravilloso es que quería historiar a la Virgen y, sobre todo, sus milagros, con un motivo absolutamente práctico, que era el de refrendar que esta «Señora» es la Milagrosa y que, por lo tanto, nosotros podíamos administrar esos cultos.

Se levanta el acta de la Cera donde supuestamente aparecían procesiones con el tema de las candelas, pero esto pasa también en Abona, pasa en otros sitios en Canarias, donde aparecen las figuras del principio de la Luz asociadas, es decir, se trata de repetir un poco ese modelo de la Virgen de Candelaria. Sabrán, por ejemplo, que la Virgen que está en la Iglesia de Santa Úrsula de Adeje, es la que más debió parecerse a la talla original. 
Es muy curioso el caso de Nuestra Señora de Tajo, lo leo rápidamente y voy acabando. Espinosa afirma: "Otra imagen dicen haber aparecido en la playa de Abona" laquí esta foto maravillosa de El Médano, me lo imagino más o menos por ahí)...

Antonio Tejera: es en el Porís.

Sergio Baucells: como dice apareció “hacia la montaña Roja”...

Antonio Tejera: es en el Porís es un lapsus.

Sergio Baucells: ah, vale perfecto. Pues dice: "Por la fiesta de la Asunción de Nuestra Señora [...], personas que las han visto se van a dicha playa y hallan velas de cera acabadas de apagar...". El tema es el mismo, idéntico. Esto ya es conocido y podemos entrar en otros tipos de cuestiones.

Ahora, tampoco sabemos cuál es exactamente la virgen de Nuestra Señora de Tajo, todo el mundo la asocia a alguna cosa, otros a otra, en fin, todo este mundo se me escapa.

Antonio Tejera: Montaña Roja se refiere a la montaña roja que está al lado del Porís, y hay ahí una confusión.

Sergio Baucells: Ahh, señores tenemos aquí a un señor que es del sur, yo soy metropolitano.

En conclusión, en esa lectura que los aborígenes tuvieron sobre la imagen de la Virgen, hay varias fases muy complicadas. Primero fue un bien de prestigio, un bien exótico, sin ninguna consideración cosmogónica. Luego pasa a ser un culto sincrético y ahora es 
cuando pasa a ser un culto cristiano, cuando Chaxiraxi desaparece y se convierte en Candelaria.

Candelaria que, además, se potencia que sea un culto integrador, no es el culto de los guanches por mucho que la escenografía lo haga así. Además eso lo hace particular, eso lo hace espectacular y lo singulariza, pero, en realidad, todos sabemos que es el culto que se va a potenciar. Bueno, se decía la Patrona de Canarias pero, en el caso de Tenerife, eso es evidente ¿no? Un culto insular que debía exceder a clases sociales y grupos étnicos. Interesa saber por qué se hace esto, porque, yo siempre lo planteo en el tema de los guanches, no interesaba para nada crear elementos que a ellos les ayudaran a potenciar su distinción étnica. Lo que interesa es asimilarlo y, de hecho, ellos lo asumen como el “Pleito de lo naturales", como un elemento para revitalizar ciertos aspectos de su vida, del episodio de la Virgen. Sin embargo, realmente lo que están reclamando es que se les trate como cristianos viejos: “Señores, que nosotros fuimos los que encontramos a esta señora, nosotros somos tan cristianos como ustedes".

No es un elemento de etnización, es decir, no es lo que pasa en México con ciertos cultos que potencian y facilitan que ciertas comunidades, como tienen un culto concreto, se les sigua tratando, digamos, como una casta. No existe una casta aborigen canaria, porque la asimilación de ellos se produce en todas las clases sociales. El pastor guanche se asimila al pastor que viene de Extremadura, el otro al ganadero, el otro al agricultor y el otro, incluso, a la clase dominante, por lo tanto, no hubo posibilidad de crear aquí una comunidad étnica de la que empieza a rememorarse en el siglo XVII.

Lo cual no tiene nada que ver con que existieran retales y continuidades culturales. A eso me refiero, que el culto a la Candelaria, 
sirvió a eso también, tanto que, el día de la Victoria, el nacionalcatolicismo lo que hace es llevar la Virgen a Santa Cruz. Lo que yo planteo es que es en el siglo XVII, cuando todo esto se consolida, con una sociedad canaria plenamente amparada en una construcción identitaria que, ahora sí, convierte al aborigen en parte propia de la sociedad canaria.

Y con esto yo acabo. Dos cosas. La aceptación de Chaxiraxi no debió ser inmediata. No conocían el monoteísmo, por lo menos en la traducción católica, por lo que tuvo que mediar ahí un periodo de relaciones interétnicas complicadas. Y el proceso sirvió a lo que estábamos planteando ahora, a una asimilación interclasista, global, en tanto que desestimó la idea de una particularización como un culto étnico propio de una comunidad única, sino de toda la isla. Así que nada, lo siento por agotarles.

Gracias. 